\title{
Quality Learning Tahfiz Design in Integrated Islamic Elementary School Sleman Special Region of Yogyakarta
}

\author{
Sigit Yuli Pramono \\ Graduate School \\ Universitas Negeri Yogyakarta \\ Yogyakarta, Indonesia \\ kaksigit@gmail.com
}

\author{
Herminarto Sofyan \\ Graduate School \\ Universitas Negeri Yogyakarta \\ Yogyakarta, Indonesia \\ hermin.uny@gmail.com
}

\begin{abstract}
This type of research can be classified as field research, descriptive qualitative in order to know the quality of tahfiz learning design in Khoiru Ummah Integrated Islamic Elementary School, Sleman, Special Region of Yogyakarta. The method used is qualitative method with interview and documentation technique. The result of the research shows that Khoiru Ummah Integrated Islamic Elementary School, Sleman, Special Region of Yogyakarta has concern for the quality of tahfiz learning design and this has been proven by several awards produced by the school. Khoiru Ummah Integrated Islamic Elementary School even got a good predicate from the community in akhlaq, the quality competence of tahfiz learning design in the implementation of elementary school management since the establishment of Khoiru Ummah Integrated Islamic Elementary School 6 years ago.
\end{abstract}

Keywords-Quality of Design, Learning Tahfiz, Learning Islamic Education.

\section{INTRODUCTION}

Tahfiz, Al-Qur'an consists of two syllables, namely Tahfiz and the Qur'an, both of which have different meanings. First Tahfiz which means to memorize, memorize from the basic memorized words from the Arabic hafidza - yahfadzu - hifdzan, ie the opponent of forgot, that is always remember and forget a bit[1]. In the history of the development of tahfiz teaching (recitation of the Qur'an) and the institution of Qur'anic tahfizul in Indonesia existed before the independence of the State of Indonesia in 1945[2]. Pesantren (cottage) located in Krapyak Yogyakarta owned by $\mathrm{KH}$ Muhammad Munawwir is believed. The development of the teaching of Quranic scholarship in Indonesia post-MHQ 1981 may be likened to a flood that cannot be dammed again. If previously only existed and developed in Java and Sulawesi, since 1981 until now almost all regions in the archipelago, except Papua, live fertile like mushrooms in the rainy season from the level of primary education to universities, both in formal and non-formal education format [3].

Currently the government maintains the continuity of tahfidz traditions that exist in Indonesia, especially in the province of Yogyakarta Special Region. Because every work of tahfidz tradition must be planned, measured and well directed as a manifestation of Islamic values. It shows that everything must be well programmed. Therefore, the government through the Ministry of Religious Affairs of DIY in January year 2015 provides circulation to madrasah / elementary school by letter number: Kw.L2.2 / Pp.Oo.11 / 1371.1 / 2015, in the letter there is improvement of education at madrasah level or elementary school, point 8 states that "All madrasah are obliged to organize tahfidz program, with the achievement of tahfidz at all levels of at least 1 juz (able to memorize 10 pages in the Qur'an scripture)"[4].

Qualified education, much needed learning design to be optimal. Briefly the definition of instructional design is "instructional design is a strategic planning of a course. It is a blueprint that you design and follow. It helps us connect all the dots to form a clear picture of teaching and learning events "[5].

The quality of tahfidz learning in school is an important factor in shaping the students into full human beings with an attitude of optimism, religion, confidence, noble character, good akhlaq to everyone. The formation of character through the Qur'an educational approach in addition to being part of the process of formation of noble character, is also able to become the main foundation in improving the degree and dignity of learners as children of the nation[6].

Integrated Islamic Elementary School provides an alternative to handle the quality of tahfidz program by forming a learning device in accordance with tahfidz. achievement. For the tahfidz the Elementary School of Khoiru Ummah Integrated Islamic Elementary School determines 2 juz [7], Learning tool became the guide and standard in the implementation of tahfidz program in Elementary School of Khoiru Ummah Integrated Islamic Elementary School. And the design of learning tools became the initial foundation before the learning began.

Based on the research background, the author was interested to conduct research related to the quality of tahfiz learning in shaping akhlaq (character) in Khoiru 
Ummah Integrated Islamic Elementary School, Sleman Yogyakarta Indonesia.

\section{RESEARCH METHOD}

The method of this research is field research method by using observation, interview, documentation and data analysis. The approach applied is phenomenological approach of naturalistic research, because this research aims to know the quality of learning design in teaching tahfidz in Khoiru Ummah Integrated Islamic Elementary School.

\section{THEORETICAL FRAMEWORK}

\section{A. Design of Learning}

Learning Theory in Behavioristic View, Learning is a change in behavior as a result of the interaction between stimulus and response. In other words, learning is a change experienced by students in terms of its ability to behave in a new way as a result of the interaction between stimulus and response[8]. Interpreting the design is a troubleshooting process. The purpose of a design is to achieve the best solution in solving the problem by utilizing several available information. Thus, a design emerges as a human need to solve a problem. Through a design, people get used to take systematic steps to solve a problem faced. [9].

\section{B. Strategy of Learning}

Learning strategies are the chosen ways to deliver the subject matter in a teaching environment, including the nature, scope, and sequence of activities that can provide a learning experience to the students. Learning strategy consists of techniques (procedures) and methods that will bring students to the achievement of goals. So, strategy is broader than method and technique. [10]. There are several methods in memorizing the Quran; (1) Method of reading carefully verses of Qur'anic verses that will be memorized by seeing the manuscripts repeatedly (an nadzar), (2) memorize per verse repeatedly so that finally memorized (al wahdah), (3) deposit or listen to a teacher (talaqqi), (4) memorize gradually the Qur'an that has been read repeatedly (tikrar) and listen to memorization to others, either to friends or to other jama'ah (tasmi ')[11]. Turkey's method of memorizing was also applied in 2015 in Malaysia, there are 7 ways to memorize in which the main point is memorizing, the system of memorization makes the students can read the Qur'an without seeing the book[12].

\section{Learning Quality Process in Tahfiz Program}

Characteristic of learning is in achieving the goals, students work with friends to determine problemsolving strategies assigned by the teacher. Each member of the group can only succeed in achieving the goal if all members work together, in which individual dependence is very high[13]. Outline of the quality of
Tahfidz's learning in Islamic Education is a common practice in assessing the development of individuals or groups spiritually and socially[14].

\section{PROGRESS TOWARDS STRONG LEARNING QUALITY}

Besides being read and pondered, tahfidz privileges, the Qur'an also needs to be memorized, transferred from writing into the heart. It is characteristic of those who are given knowledge [15]. Implementation of tahfidz program can improve students' learning motivation [16].

Tahfidz learning can also create a generation of religious and mutual affection among others. In which this generation is needed for sustainability, human civilization in the days to be. Minister of Religion, Lukman Hakim Saifuddin on graduation of tahfidz Madrasah on Thursday 17 December 2015, in GOR Amongrogo, Yogyakarta, Indonesia conveyed "Concerns of some sides about clerical crisis in the future in line with the swift flow of modernization and globalization has been answered already. Initiatives undertaken by the ranks of the Regional Office of the Ministry of Religious Affairs Yogyakarta organizes tahfidz program in Madrasahs to create the cadre of scholars who have the capacity to comprehend AlQuran in kaffah deserves the highest appreciation"[17]. This program is the answer to generations of religionists in the future.

The investment of tahfidz in Khoiru Ummah Integrated Islamic Elementary School is expected to fortify children from unfavorable influences, to continue their higher education and its benefits when they are in the surrounding environment to protect themselves from negative things, to be able to familiarize themselves with the existing rules in the Qur'an[18]. To strengthen it also, the management of tahfidz for now especially in Khoiru Ummah Integrated Islamic Elementary School assisted by sides from outside who are competent in the implementation of tahfidz with institutions that have high credibility[19]. All the theories will succeed if they can combine students' spirit and teachers' commitment [20]. The aim of tahfiz is widely to create hafidz Qur'an rohmatan lil alamin (a blessing for the whole nature). Not only have a piety in worship but also have social piety. Children not only think about themselves but also people / society[21].

Basic tahfidz education for students as delivered by teachers of Khoiru Ummah Integrated Islamic Elementary School for children's education is their provision for them when they are being adults. Success such as those in the educational sector are evolving, children are more enthusiastic in memorizing, so they already have ghiroh (strong desire) to memorize independently, so that their memorization has gone beyond what is learned[22]. The guidance system in memorizing Al Quran is using private system and self- 
supporting system, the supporting factor is the students' own will, due to the encouragement and motivation of the parents, and not far from the guidance of tahfidz teachers[23].

Khoiru Ummah Integrated Islamic Elementary School requires teachers who can bring students closer to emotional ties, not fierce but firm and able to please students. With teachers who are fun in how to teach, it makes the children not bored. The children can follow tahfidz well and correctly, when observed they will be very capable once. Coupled with the process of guidance on Islamic norms so that they have a deep understanding, if being a hafidz al Qur'an their behavior will be like this. With such a coaching process[24].

The quality of education is an important factor in school, an important factor of children, parents, teachers, and the environment. Factors of friend is very influencing, if his friend is lazy, another child will also be lazy[25].

Schools that have different educational qualities can be seen in several variables such as value acquisition, student behavior, intra and extra-curricular learning process, physical condition, and library network. Student behavior, learning process, the acquisition of student value in reading quantity can memorize how many juz, how many letters or how many verses become variables of quality difference elsewhere[26] Things that affect the school education environment and school management are the influence of the educational environment is very important, the location of the place away from noise or crowd, so it is conducive [27].

The appreciation of education in Khoiru Ummah the Integrated Islamic Elementary School of the community is very good due to the Khoiru Ummah Integrated Islamic Elementary School students are prioritizing morality, so it is very acceptable. The award of parents whose children attend Khoiru Ummah Integrated Islamic Elementary School is also very grateful for the hard work of educators who educate good morals in school[28]. Interest in the development of education in Khoiru Ummah Integrated Islamic Elementary School is eager to develop this tahfidz program, itself wants to become an international Elementary School, trying to be better in the learning process [29].

\section{A. Learning Quality by Learning Organization Strategy}

Learning will achieve high quality if it has several learning factors. There are four variable of factors affecting student learning: (1) teacher, (2) context: students, school and class, (3) process: teacher performance, spirit in teaching, and student behavior (motivation), and (4) short term (proficiency) and long term (proficiency or proficiency in a particular field[30]. The quality of learning for the future is to become a qualified school for referrals learners, parents referral attend school at Khoiru Ummah Integrated Islamic Elementary School, itself wants to be an example of another elementary school, newly developed in terms of the quality of the process of its learning[31].

\section{RESEARCH RESULT}

To realize the vision-mission in terms of tahfidz progress, the teachers build learning organization. The learning organization can support the learning progress of tahfidz. Graduates of SD IT Khoiru Ummah currently are in an effort to meet the target and remain focused on the capability of tahfidz memorization of santri 2 (two) juz.

Through the socialization of all components have a view of the same vision and mission and purpose in carrying out all activities. Implementation in realizing the quality of learning tahfidz as follows:

- Enliven the learning organization by the teachers. They have the initiative to form a social media group. In social media group is used for sharing knowledge about improving the quality of learning tahfidz.

- The school committee provides socialization on the learning of tahfidz which the flagship and characteristic of Khoiru Ummah Integrated Islamic Elementary School is.

- Students get good service from the teachers from grade 1 (one) to class (six). Teachers have been trained in teaching children tahfidz Qur'an well and optimally.

- Developing learning tools by forming a team of tahfidz learning tool developers in Khoiru Ummah Integrated Islamic Elementary School.

- Optimizing school facilities such as audio Mp3 every morning, use of active Mic Speaker for the process of learning tahfidz Qur'an memorizing.

- Conducting Formative and Sumative Tests to students during a half year for tahfidz Qur'an Learning.

To obtain maximum learning as a target of 2 (two) juz during class 1 (one) to grade 6 (six), it needs creativity from teachers, managers, and leaders to maximize learning tahfidz, there are several programs that are given to children in order to maximize learning tahfidz include:

- The tahfidz extracurricular program, this program is very important to prepare students in order to improve the quality of students' tahfidz learning outcomes.

- Religious practice (reading the Qur'an, praying, and worshiping), this program is done before the study of subjects in the field of science.

- The practice of writing, coloring, painting the letter of the Qur'an commonly called calligraphy in students.

- Familiarize children to learn using audio - visual about the deepening of the Qur'an. 
- Conducting study visits to the lodge, a learning resource, a religious museum in order to enrich the insight of Diversity as a form of implementation of tahfidz Qur'an learning.

- Establish tahfidz learning consultation service for parents and teachers as a connector of ideals formed in vision - mission.

The guides used in tahfidz learning have been formed by the learning device development team at Khoiru Ummah Integrated Islamic Elementary School. The following are the learning tools created:

\section{Tahfidz curriculum}

The foundation of the curriculum is formed due to the physiological basis of the people of Yogyakarta, Indonesia is deeply religious. The tradition of tahfidz or memorization of the Qur'an already existed before the independence of Indonesia.

2. Annual Program

This cultivation program breaks down the activities for one year. Activity of one year greeting from class 1 (one) to grade 6 (six).

3. Semester Program

The semester program derives from the annual program; the program is formed to take steps for one semester.

4. Syllabus

Syllabus is a schedule contract that needs to be known by the parents, the school leader and implemented by the teacher in each class.

5. Lesson plan

The plan for the implementation of tahfidz learning begins 60 minutes before the subject of science.

By dividing the time of implementation tahfidz as follows:

\section{a) 10 minutes}

With a description of activities, opening greetings, prayers to learn, preparing a book / Qur'an that will be memorized.

b) 45 minutes

With the description of the students; preparing the book / Qur'an teacher checks each student, students prepare themselves to follow the cue from the teacher, students tidied themselves in the place respectively, and students follow the memorization delivered from the teacher for 40 times repetition. Students during memorization still read or pay attention to writing book / Qur'an. This method is called the tikrar method [32]. When memorizing without stopping, whenever a child is busy the teacher approaches without being reprimanded. (So that noisy students do not interfere the students' memorizing activity)

c) 10 minutes

With a description of closing activities, the teacher gives the signal after the recitation; the students are invited to discuss the material to be memorized in the next day. Once the discussion is enough then the students put the book and the

Qur'an in the bag, continued with closing prayer.

6. Assessment Instruments.

This instrument is used as a guide to perform formative tests and summative tests. Formative tests and summative tests are still using the same instrument only the nature of the different exams if the instruments used in the formative exam only exercise. The instrument used in summative is final test.

The assessed indicators in the achievement of the competence of memorizing tahfidz Qur'an for students are as follow:

a) Students can explain the condition of each memorized letter that is mastered.

b) Students can call each line (paragraph) in the letter and read out.

c) Students can read fluently every letter in the Qur'an

d) Students can sort each verse from a letter in the Qur'an.

Developing learning tools eases the tahfidz teacher to educate his students. Annual program, semester program and syllabus can measure learning achievement. Learning is neatly designed by implementing the Lesson Plans. The developed valuation instrument is useful for analyzing the extent to which learners' ability to follow learning is seen from the value of the results obtained.

\section{SPECIAL FINDING}

A. Planning tahfidz Learning in Khoiru Ummah Integrated Islamic Elementary School

Based on interviews with principal and teachers, the authors presented general program planning of quality of learning in SD IT Khoiru Ummah Sleman. General planning includes improvement planning Quality of learning is a general program with targets covering tahfidz program from planning, implementation, to evaluation. Programs to improve the quality of learning tahfidz in general are:

1) Teachers of tahfidz plan the program to improve the quality of Islamic education that will be implemented in schools, including lesson plans, syllabus, enrichment materials and others.

2) Teachers of tahfidz discuss plans for the quality of the tahfidz learning enhancement program with the subject, soliciting support and input. This is important, because each program must be supported by the Principal.

3) Teachers of tahfidz discuss the teaching plan to use the learning model.

4) Socializing the vision and mission of the tahfidz curriculum targets to all pupils, students, teachers, employees. 
5) Conduct analysis of program success through formative test and summative test.

When the author asks questions about the quality of learning tahfidz in Khoiru Ummah Integrated Islamic Elementary School, the headmaster replied: "Planning all students studying at Khoiru Ummah Integrated Islamic Elementary School able to memorize two juz juz 29 and 30 (calculated in the sheet there are 16 pieces in book of the Qur'an)"'[33].

Another question was then given to the Principal Khoiru Ummah Integrated Islamic Elementary School how to integrate tahfidz in school: "We (Principals and Teachers) incorporate learning in those classes morning from 7 a.m. to 8 p.m., initially the children do dhuha prayer first, and then they sit in circle and guided by homeroom teacher to memorize. 15 minutes before activity, they follow literacy activity (reading library books)".

When the author asked the teacher of Islamic religious education of Khoiru Ummah Islamic Elementary School Sleman about the quality of learning tahfidz in Khoiru Ummah Integrated Islamic Elementary School Sleman, Islamic religious education teacher replied: "... School make programs and preparation of teaching seriously, assisted by team of curriculum experts' tahfidz, experts in making learning devices to ensure the learning device products before use have been validated by experts. "[34].

Then the author asked the teacher at Khoiru Ummah Integrated Islamic Elementary School about the quality of learning design tahfidz for learners: "After graduated , the students are developed in community, developed thing from graduate of Khoiru Ummah Integrated Islamic Elementary School are Akhlaq, able to innovate, able to work the new who want to be the unifying agents of change of society "[35]. Obviously, education provides community harmony and creates peace. Rohmatan Lil Alamin (being the love of the whole world), the graduating learners will later become part of a peaceful coexisting society[36].

Based on the data and facts as presented in the above interview section, respondents' answers indicates that the quality planning of teaching learning tahfidz in Khoiru Ummah Primary School of Islamic Elementary School Sleman is good in planning, for example: The teacher must prepare a program and preparation of the of a serious teaching plan. This proves that the effort is aimed to improve the quality of learning tahfidz in Khoiru Ummah Primary School Integrated Islamic Elementary School Sleman.

\section{B. Implementation of the Quality of tahfidz Learning at Khoiru Ummah Primary School Integrated Islamic Elementary School}

Based on interviews with Principal Khoiru Ummah Integrated Islamic Elementary School Sleman, the writer exposes things about the implementation of the quality of tahfidz Learning: "... As stated in the planning, the expectation of two juz in the al Qur'an are juz 29 and 30 (calculated in the sheet there 16 pages in the Qur'an) every week there are three days of accompaniment with the teacher on Tuesday, Wednesday and Thursday. 7 am to 8 am in tahfidz. program ... "[37]

In the morning, the children memorize the verses, after a break or after lunch time there is a target of rote practice. Children are also eager to pursue the target of rote training. For a pretty good climate in a cool area of many green plants, make the sauna conducive [38].

Another question is then given to Islamic religious education teachers how to apply learning tools that have been developed for implementation: "...The learning process elsewhere differs in the way of teaching, in Khoiru Ummah Integrated Islamic Elementary School every teacher has the ability in teaching tahfidz himself .."[39].

The analysis of the teachers was used as an ingredient in the design of tahfidz learning in Khoiru Ummah Integrated Islamic Elementary School. Empirically the making of tahfidz learning design must involve experts who have much experience in terms of memorizing the Qur'an. Together with the experts the level of validity used is very high, few mistakes make effective and efficient. Effective and efficient are one of the characteristics in terms of management.

Progress forward with the development of education technology / information technology, there is a lot of information that is not clear and less valid then the students are able to fortify from the things that are less good [40].

Then a question was given to the students of Class VI SDN AnNizam Medan in the learning process of Islamic Education. And the answers given; "tahfidz lesson is given every 3 days for a week in Tuesday, Wednesday, and Thursday. Teaching in Primary School is very fun for the friendly teachers with their students. A clement school condition which is friendly to the children provides pleasant atmosphere to create a home school here. This school has a pre-eminent tahfidz program, a program we love. I want to be Hafidz (a person who memorizes the Qur'an) want to please many people, serve both parents and be useful to the nation and the State... "[41].

From the data above, it seems that the Primary School of Sleman Khoiru Ummah Integrated Islamic Elementary School has a great concern in improving self-learning quality Tahfidz. All activities of learning process have been done arranged in planning, so all of this becomes obligatory to be done well by the students, teachers, and guardians. Everything has been well established by the principal, and the team from developing the school's learning design through the planning process. 


\section{Quality Evaluation of Tahfidz Learning Design}

If the student does not meet the targets set, then the student must do something as specified. According to interviews conducted by the author with the deputy head of the Khoiru Ummah School of Integrated Islamic Elementary School Sleman: "...School step that we take if the child does not meet the target then the school provides tahfidz extracurricular service every Saturday but not all students participate. Only certain students follow tahfidz extracurricular. And the rest of the children still study at home with family ...'[42].

Another question was also given to the head master of the Khoiru Ummah Integrated Islamic Elementary School on the evaluation of the quality of Tahfidz's learning and the implementation of tahfidz's test at Khoiru Ummah Integrated Islamic Elementary School: "At the end of each semester the children are tested in that class, then for murojaah (repetition of rote) in the class is mostly also repeated again that has been memorized and the target class. The test tested includes fluency, correctness of reading, it is conducted in the end of semester...’[43].

Conventional general criteria that something qualified must have a good value or meaning, the criteria that can be valued in Khoiru Ummah Integrated Islamic Elementary School obtained good value in the community are the achievement, good manners, and mingle. Judged by society also from self-reliant, have honest self-qualities uphold tolerance like that in al Qur'an reads (lakudinkum waliyadin) For you your religion, for me my religion[44].

Tahfidz quality in Islamic education if associated with the learning process can be called learning which is still conventional with behavioristic techniques. We can understand all the needs needed in the present day. Readiness is done with self-change. Khoiru Ummah Integrated Islamic Elementary School before starting the learning of audio listener students in the morning, the teachers also use audio and audio visual. Audio is better and easier to memorize[45].

The advantages of the audio visual itself simplify in delivering and accepting learning or information and can avoid misunderstandings, encourage the desire to know more, this is due to the interesting audio visual properties with images made as attractive as possible to make children interested and have the desire to know more, perpetuate the understanding gained, besides to displaying images, graphs, diagrams or stories. So that it is to perpetuate understanding. Learning that is absorbed through the visual (visual) as well as with the hearing (audio) can accelerate the absorption of learners in understanding the lessons delivered[46].

Based on the above presentation, the Evaluation of the Quality of tahfidz Learning is done seriously. This is done to improve the quality of the learning process tailored to the planning and implementation.

\section{CONCLUSION}

The conclusion of this study is perfect learning design that is used in learning Khoiru Ummah Integrated Islamic Elementary School the components of all tahfidz activities are:

a) tahfidz Syllabus

b) Implementation plan of tahfidz learning

c) tahfidz curriculum

d) tahfidz semester program (half year)

e) tahfidz annual program

Some indicators of success achievement of tahfidz learning are students can memorize well, continue the verse, and know the meaning of a letter that has been memorized in the Qur'an.

The quality of tahfidz learning in school is an important factor in shaping students into full human beings with optimism, religion, self-confidence, noble character, and good akhlaq to everyone. The appreciation of education in Khoiru Ummah the Integrated Islamic Elementary School of the community is very good because the Khoiru Ummah Integrated Islamic Elementary School students are prioritizing morality, therefore it is very acceptable. The parents whose children attend Khoiru Ummah Integrated Islamic Elementary School are also very grateful for the hard work of educators who educate good morals in school.

\section{REFERENCES}

[1] M. Yunus, Kamus Arab Indonesia. Jakarta: Hindakarya Agung, 1989.

[2] A. Fathoni, "Sejarah \& Perkembangan Pengajaran tahfidz Al-Quran di Indonesia," 17-Feb-2018. [Online]. Available: http://www.baq.or.id/2018/02/sejarah-perkembanganpengajaran-tahfidz.html. [Accessed: 14-May-2018].

[3] A. Sasongko, "Tren Menghafal Alquran Makin Berkembang," Republika, 10-Jul-2017. [Online]. Available: http://www.republika.co.id/berita/dunia-islam/islamdigest/17/07/10/osvlak313-tren-menghafal-alquran-makinberkembang. [Accessed: 14-May-2018].

[4] Noor, "Surat Edaran Kepala Kantor wilayah Kementrian Agama D.I Yogyakarta." Kantor wilayah Kementrian Agama D.I Yogyakarta, 01-Jul-2016.

[5] M. Gary R, S. Ross, and J. Kemp, Designing Effective Instruction, 5th ed. New Jersey, 2007.

[6] Zulfitria, "Peranan Pembelajaran tahfidz Al Quran dalam pendidikan karakter di Sekolah Dasar.," Junrnal Kaji. Penelit. Pendidik. Dan Pembelajaran, vol. 2, no. Naturalistic, pp. 124-134, Apr. 2017.

[7] Yayasan Bina Khoiru Ummah, "Keunggualan Khoiru Ummah Integrated Islamic Elementary School." Nov-2012.

[8] H. B Uno, Orientasi Baru dalam Psikologi Pembelajaran. Jakarta: Bumi Aksara, 2006.

[9] B. B. Seels and R. C. Richey, Teknologi Pembelajaran: Definisi dan Kawasannya. Jakarta: Publishing Unit State University of Jakarta, 1994.

[10] Strategi Belajar Mengajar suatu Pengantar. Jakarta: PPLPTK, 1984.

[11] A. Akbar and M. Ismail, "Metode tahfidz Al Qur'an di Pondok Pesantren Kabupaten Kampar.," Jurnal Ushuliddin, vol. 24 , no. 1, Jun. 2016.

[12] S. Arifin, M. Abdullah, and K. Ahmad, "Method on Memorization the Quran in Malaysia: A Study in Darul Ruba Institute, Malaysia," GB15Thai Conf., Feb. 2015. 
[13] H. B Uno, Perencanaan Pembelajaran. Jakarta: Bumi Aksara, 2007.

[14] S. Lubis, "Cultural Quality in Islamic Education at ANNIZAM Elementary School Medan North Sumatera Indonesia," J. Int. J. Sci. Res., vol. 6, no. 3, Mar. 2017.

[15] A. A. L. Abdur Rauf, Pedoman Dauroh Al Qur'an Penduan Ilmu Tajwid Aplikatif. Jakarta Timur: Markaz Al Qur'an, 2005.

[16] M. Shofwah, "Penerapan program tahfidz Al Qur'an pada Pembelajaran Materi Al Qur'an di Madrasah Diniyah Al Karim Ngeni Kepuhkiriman Weru Sidoarjo (Indonesia)," Thesis, Sunan Ampel State Islamic University, Surabaya, 2013.

[17] Khoiron, "Program tahfidz di Madrasah Solusi Krisis Ulama Masa Depan," kemenag.go.id, 18-Dec-2015. [Online]. Available:

https://kemenag.go.id/berita/read/316057/program-tahfidzdi-madrasah-solusi-krisis-ulama-masa-depan. [Accessed: 16-May-2018].

[18] "Documentation of Khoiru Ummah Integrated Islamic Elementary School.".

[19] "Interview with the teachers of Khoiru Ummah Integrated Islamic Elementary School, Special Region of Yogyakarta," 26-Dec-2017.

[20] A. Mazaayaa, Panduan menghafal al-Quran. Darul Nu'man, 1996.

[21] "Interview with the teachers of Khoiru Ummah Integrated Islamic Elementary School, Special Region of Yogyakarta," 26-Dec-2017.

[22] "Interview with the teachers of Khoiru Ummah Integrated Islamic Elementary School, Special Region of Yogyakarta," 26-Dec-2017.

[23] A. Nashir and A. Halib, "Sistem Pembinaan Halaqah Terhadap Kecerdasan Emosional Santri di Markaz tahfidz Al Qur'an Al Birr," J. Tarbawi, vol. 1, no. 2.

[24] "Interview with the teachers of Khoiru Ummah Integrated Islamic Elementary School, Special Region of Yogyakarta," 26-Dec-2017.

[25] "Interview with the teachers of Khoiru Ummah Integrated Islamic Elementary School, Special Region of Yogyakarta," 26-Dec-2017.

[26] "Interview with the teachers of Khoiru Ummah Integrated Islamic Elementary School, Special Region of Yogyakarta."

[27] "Interview with the teachers of Khoiru Ummah Integrated Islamic Elementary School, Special Region of Yogyakarta," 26-Dec-2017.

[28] "Interview with the teachers of Khoiru Ummah Integrated Islamic Elementary School, Special Region of Yogyakarta," 26-Dec-2017.

[29] "Interview with the teachers of Khoiru Ummah Integrated Islamic Elementary School, Special Region of Yogyakarta," 26-Dec-2017.

[30] D. R. Cruickshank, "Research that Informs Teachers and Teacher Educators.," Phi Delta Kappa Educ. Found., 1990.

[31] "Interview with the teachers of Khoiru Ummah Integrated Islamic Elementary School, Special Region of Yogyakarta," 26-Dec-2017.

[32] Tim Tikrar, Tikrar Qur'an Hafalan. Bandung: Syamil Qur'an, 2015

[33] "Interview with headmaster fo integrated Islamic elementary school," 14-Mar-2018.

[34] "Interview with teacher of Islamic religious education in integrated Islamic elementary school," 26-Dec-2017.

[35] "Interview with teacher of Islamic religious education in integrated Islamic elementary school," 26-Dec-2017.

[36] "Documentation of Khoiru Ummah integrated Islamic elementary school.".

[37] "Interview with headmaster fo integrated Islamic elementary school," 14-Mar-2018.

[38] "Interview with headmaster fo integrated Islamic elementary school," 14-Mar-2018.

[39] "Interview with teacher of Islamic religious education in integrated Islamic elementary school," 26-Dec-2017.

[40] "Documentation of Khoiru Ummah integrated Islamic elementary school.".
[41] "Interview with student fo Khoiru Ummah Integrated Islamic Elementary School," 18-Mar-2018.

[42] "Interview with headmaster fo Khoiru Ummah Integrated Islamic Elementary School," 14-Mar-2018.

[43] "Interview with headmaster fo Khoiru Ummah Integrated Islamic Elementary School," 14-Mar-2018.

[44] "Documentation of Khoiru Ummah integrated Islamic elementary school.".

[45] "Documentation of Khoiru Ummah integrated Islamic elementary school.".

[46] S. Nana, Teknologi Pengajaran. Bandung: Sinar Baru, 1989. 